\title{
The genus Krithe (Ostracoda) from the Campanian and Maastrichtian (Upper Cretaceous) of the northern US Gulf Coastal Plain
}

\author{
T. MARKHAM PUCKETT \\ Geological Survey of Alabama, 420 Hackberry Lane, PO Box O, Tuscaloosa, AL 35486-9780, USA.
}

\begin{abstract}
The ostracode genus Krithe is one of the most common genera in the Upper Cretaceous (late Santonian to Maastrichtian) deposits of the northern Gulf Coastal Plain of North America. Although it is never abundant, the genus occurs in sediments that were deposited under a wide range of palaeoenvironments, including nearshore sandy marls to offshore, nearly pure, chalk. The taxonomy of this taxon has been problematical, and what is herein considered to be a single species, $K$. cushmani, has been referred to in the literature under five different names. Two morphotypes were observed: relatively large individuals with 'mushroom'-shaped vestibules collected from chalk, and smaller individuals with pocket-shaped vestibules collected from nearshore deposits. Species of Krithe have been hypothesized to be useful in estimating dissolved oxygen concentration in ancient ocean floors, based on details of their morphology. Whereas the relationship between size and environment corroborates with previous predictions (larger individuals live in deeper water), the morphology of the vestibules contradicts predictions (the larger vestibules occur in the nearshore deposits and the smaller, more constricted vestibules occur in the chalk). A causal relationship between environment and morphology is discussed. $J$. Micropalaeontol. 16(2): 145-157, October 1997.
\end{abstract}

\section{INTRODUCTION}

The purpose of this research is twofold: (1) to establish the correct taxonomic status of individuals of Krithe in the Upper Cretaceous deposits of the Gulf Coast of North America; and (2) to correlate the internal and external morphology of these individuals with palaeoenvironment. Individuals of the genus Krithe, although never abundant, are present in sediments deposited under a very wide range of palaeoenvironmental conditions in the Upper Cretaceous deposits of the northern Gulf Coastal Plain of North America. Sediments that contain Krithe range from marly, fossiliferous sand with abundant oysters, deposited under nearshore conditions well above wave base, to nearly pure chalk, deposited in offshore conditions well below wave base. The alpha taxonomy of these individuals remains a confused issue. Alexander (1929) gave the name Krithe cushmani to specimens of the genus found in the lower Taylor (=Sprinkle Formation) of Texas. Schmidt (1948) named specimens of the genus from the Marshalltown Formation of Delaware Krithe postprojecta on the basis of an elongate carapace with a posteroventral margin extension. This $K$. postprojecta form is herein considered to be the male of $K$. cushmani. Swain (1952) found specimens similar to Schmidt's (1948) K. postprojecta from the subsurface of the Peedee (?) Formation of North Carolina but thought they differed from that taxon by a more extended posteroventral margin and the presence of a pit at the posterior end of each carapace. Similar to those of Swain's (1952), specimens found by Benson \& Tatro (1964) displayed pits in the posterior end of the carapace. Benson \& Tatro (1964) considered them to be a new species and gave them a new name, K. swaini. Finally, Crane (1965) found specimens of the genus that were similar to Alexander's (1929) $K$. cushmani in many of the Gulf Coast Upper Cretaceous formations. These also had pits at the posterior end and had a more blunt posterior terminus; thus these specimens were given a new name, Krithe whitecliffsensis.

All of these forms are considered herein to be of a single species, Krithe cushmani, with the confusion arising from two sources: a lack of recognition of sexual dimorphism and second, from some, the omission of a description of the pits at the posterior end of the carapace of the species. In none of these aforementioned taxonomic studies were the configuration of the marginal pore canals or the nature of the anterior vestibulum described or considered, both features now considered essential for identification of species.

Individuals of Krithe cushmani are, however, morphologically variable in the Upper Cretaceous of the Gulf Coast, even considering sexual dimorphism. Specimens collected from the chalky deposits are generally larger than those from the more terrigenous, and ostensibly more nearshore, deposits and differ in details of the vestibule and general outline. Work by Peypouquet (1975, 1979, Peypouquet et al., 1986) on fossil and recent specimens of Krithe hypothesized that the size of the carapace, shell thickness, overlap, and vestibule size are directly related to certain (palaeo)environmental parameters, chiefly the depth and the amount of dissolved oxygen (DO). Van Morkhoven (1972) reported that species of Krithe living in shallow depths in the Gulf of Mexico were smaller than those living on the continental slope. Peypouquet $(1975,1979)$ took this observation a step farther and hypothesized that size in species of Krithe varies proportionately with depth. Whatley \& Quanhong (1993), however, plotted the depth versus valve length of several species of Krithe from the South China Sea and observed that the greatest increase in size of individuals of Krithe is correlated with a maximum decrease in temperature, suggesting that the increase in size of individuals is a function of temperature rather than depth per se.

Peypouquet (1975, 1979; Peypouquet et al., 1986) also suggested that the size (area) of the anterior vestibulum in individuals of Krithe was inversely proportional to the dissolved oxygen (DO) concentration. Whatley \& Quanhong (1993) and Coles et al. (1994), however, rejected this hypothesis. Whatley \& Quanhong (1993) cited the presence of individuals of Krithe with 


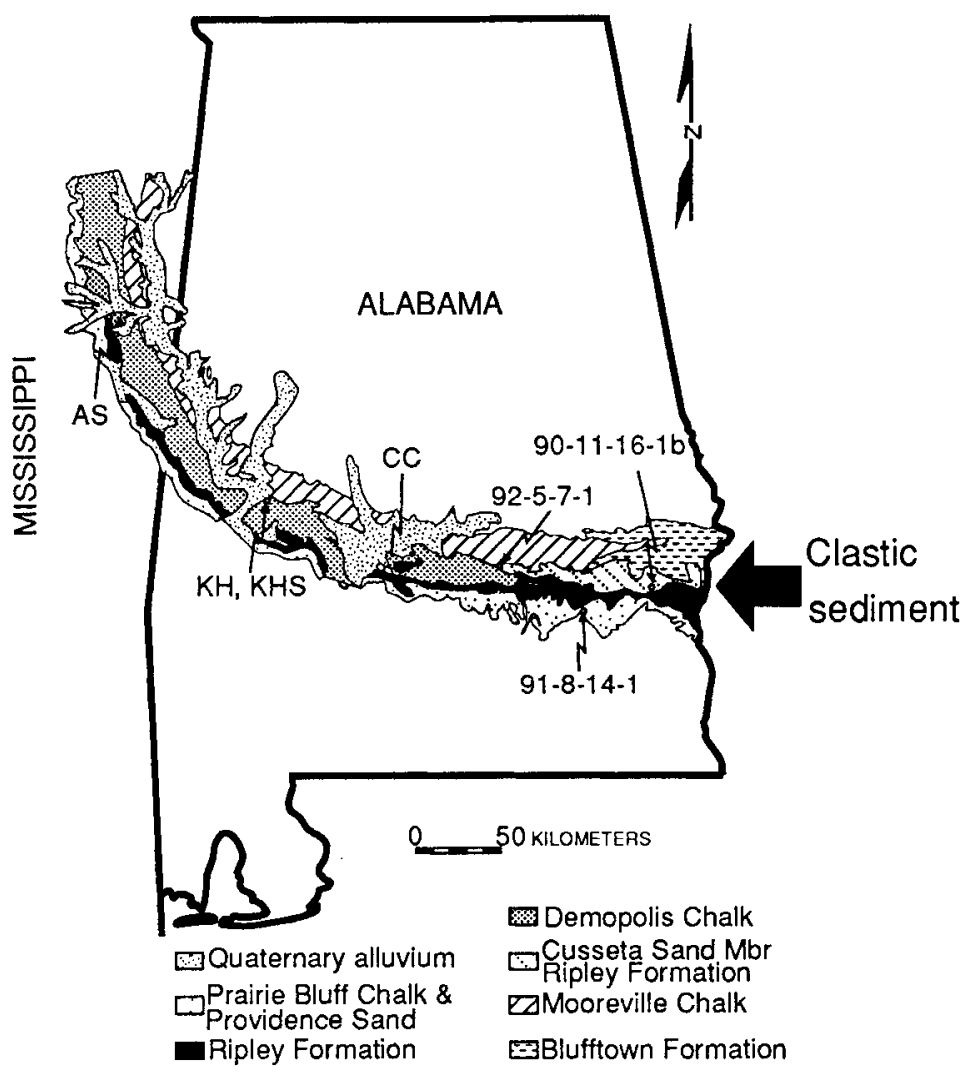

Fig. 1. Map showing Upper Cretaceous formations and sample localities.

the total range of anterior vestibule types within individual samples collected from the South China Sea and the presence of specific types of vestibules in a wide range of environments. Coles et al. (1994) reported similar observations of Krithe from the Cenozoic deposits of the North Atlantic.

McKenzie et al. (1989) also suggested that temperature, along with depth, influences the size of individuals of Krithe. McKenzie et al. (1989) attempted to test the validity of Peypouquet's hypotheses regarding the relationship between the area of the vestibule and DO concentration with living specimens of Krithe praetexta praetexta collected from the Gullmar Fjord on the western coast of Sweden, a region where the dissolved oxygen content is known. Five variables of the anterior vestibule of these specimens were measured from digital images. These data were analysed by canonical variate analysis. Results of the analyses indicated simply that the area of the vestibule is different for males and females and for left valves and right valves. The relatively large size of the vestibule was judged to correspond to DO contents of about $4.5 \mathrm{ml}^{-1}$, which corresponds well to the observed range in the fjord. Individuals of Krithe were also observed to have vestibules that supposedly indicate DO levels lower than the values measured while the collections were being taken. These differences in the size of the vestibules among samples collected from the same environment were attributed to seasonal upwelling of deeper oxygen-deficient water. Whatley \& Quanhong (1993) criticized this interpretation as being too complex and, in effect, ad hoc.
The systematic variations in carapace size and vestibule area in specimens of $K$. cushmani from the Gulf Coast of Alabama and Mississippi were originally hypothesized to result from differences in paleo-oxygen levels between the nearshore, largely terrigenous paleoenvironments and the offshore, chalky paleoenvironments. Puckett (1992) demonstrated that species of Cytherella are much more abundant in the offshore, chalky deposits than in the more nearshore deposits and may account for as much as two-thirds of the total ostracode fauna. Whatley and Quanhong (1993) determined that a dominance of species of Cytherella signals a reduction of DO concentration from normal-marine conditions because brachial plates on the third thoracic leg allow the active absorption of oxygen during movement, and the adults brood their young within the carapace, thus protecting them from a hostile environment. The dominance of Cytherella in the chalky deposits in the Upper Cretaceous sediments of the Gulf Coast, then, suggested the possibility that the bottom water had a reduced level of oxygen from normal marine conditions. If the carapace size and area of vestibule of specimens of Krithe are directly related to the DO concentration, then these conditions would provide an external check on the hypothesis that the dominance of Cytherella in the chalk resulted from reduced DO.

\section{MATERIALS AND METHODS}

A large number of individuals of Krithe cushmani were picked for this study (more than 850 ), as only those with open and 


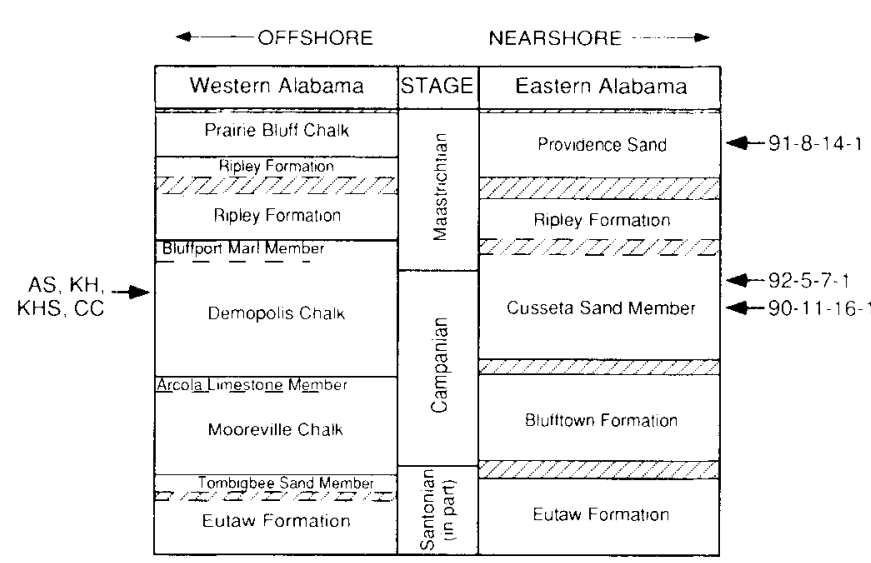

Fig. 2. Stratigraphy of the marine portion of the Upper Cretaceous exposed in Alabama, with approximate ages of the samples used in this study.

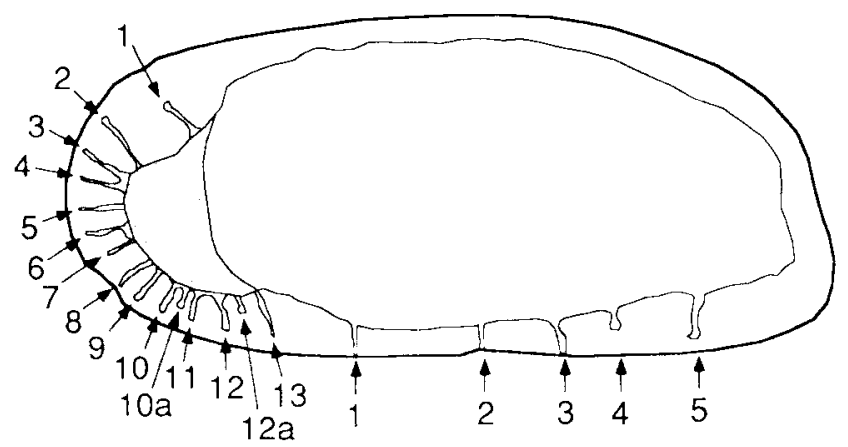

Fig. 3. Line drawing of individual 91-8-4-3 showing vestibule measurement area and numbering system of anterior and ventral marginal pore canals (see Fig. 6.18 for scale). unbroken vestibules could be measured. Individuals collected from nearshore (terrigenous-clastic), somewhat intermediate (marl) and offshore (chalky) deposits (Fig. 1) were analysed. Figure 2 shows the stratigraphy of the marine Upper Cretaceous sediments that crop out in Alabama and the approximate age of each of the samples. Table 1 lists sample numbers, formations, and sample locations. The specimens were photographed using transmitted light and printed at the same scale. The photographs were scanned into a PC-formatted computer with a Hewlett Packard ${ }^{\circledR}$ ScanJet Plus (model HP9195A) flatbed scanner and Hewlett Packard ${ }^{\text {(B) }}$ Scanning Gallery Plus (1990, version 5.4) software. The PC format was then translated to a Macintosh ${ }^{8}$ format using the Apple File Exchange ${ }^{\circledR}$ program (version 1.1, 1988). The image was then imported into the Image program (Rasband, 1992), public domain image analysis software, where the actual measurements were made.

The length and height of each valve and the area of the vestibule of each specimen were measured. The measurements were calibrated by measuring length along a line on a scanned image of the micrometer then pasting this line on each of the photographs in turn. The area of the vestibule was measured by selecting $n$ number of points (usually $30-50$ ) along the outline of the vestibule shaded area on Fig. 3. As a check on repeatability each individual of Krithe was measured four times, the average of which was used as the area of the vestibule for each specimen. Basic statistics and the bivariate plots were performed using StatView 4.0 (Abacus Concepts, 1992). Microsoft Excel ${ }^{\circledR}$ version 4.0 (Microsoft Corporation, 1992) was used as the spreadsheet to compute averages and ratios. A camera lucida attachment was used on a Wild M5-49287 binocular microscope for making line drawings. All the line drawings (Figs 4-6) are at the same scale.

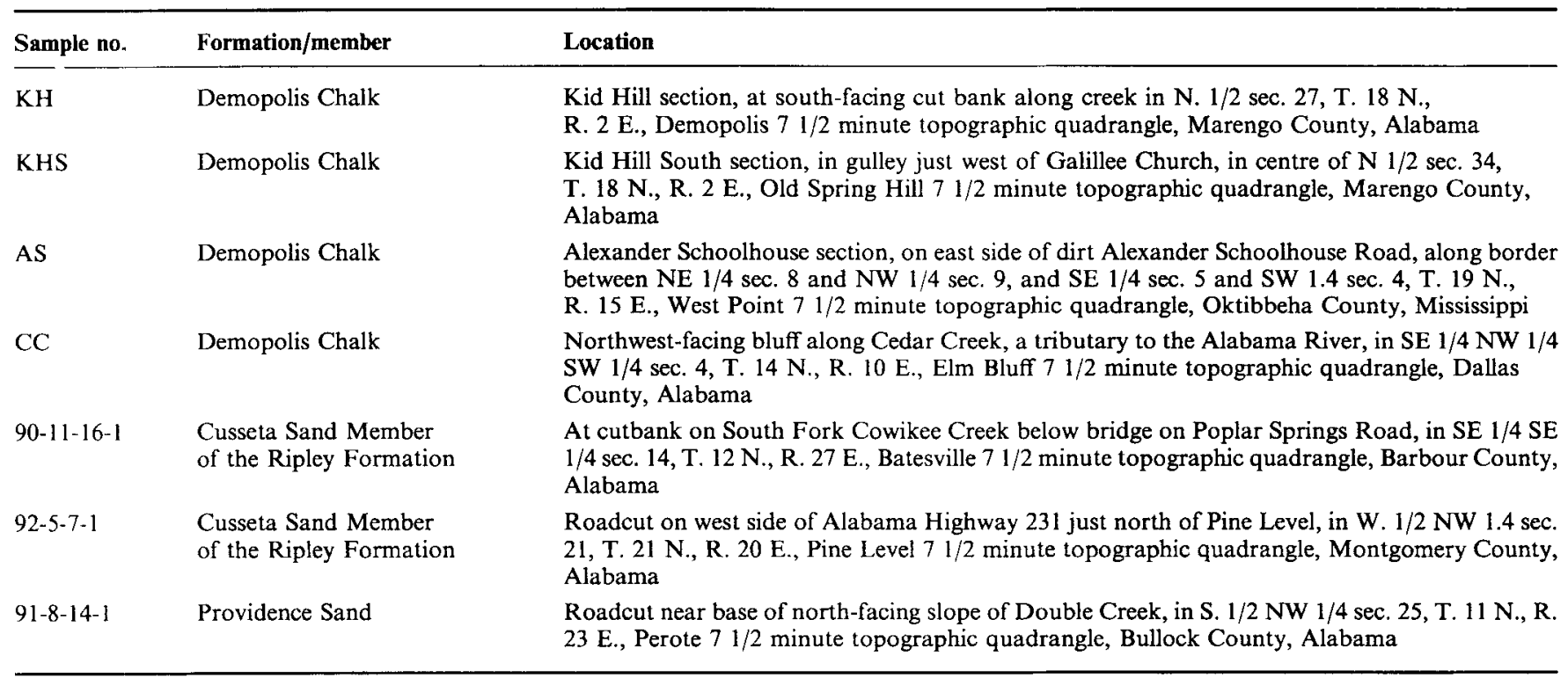

Table 1. Sample numbers, formations and members, and locations of samples from which specimens were collected. 
Puckett

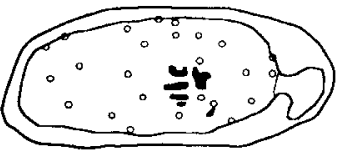

1

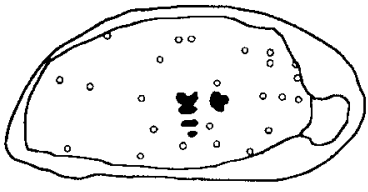

4

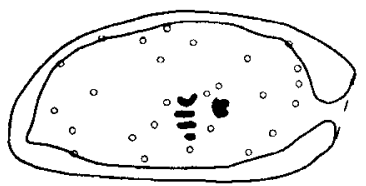

7

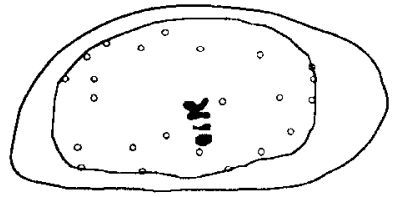

10

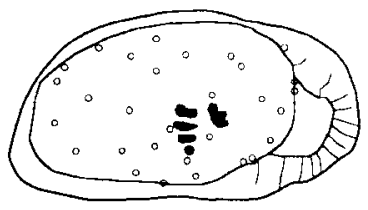

13

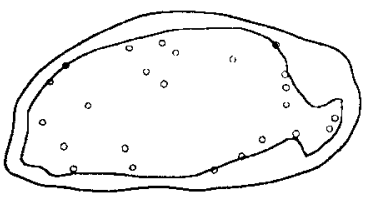

16

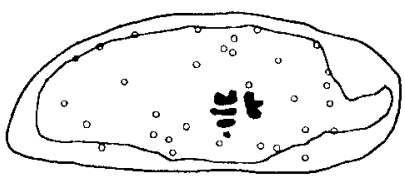

2

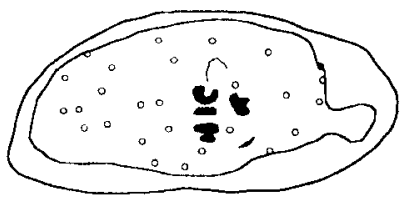

3

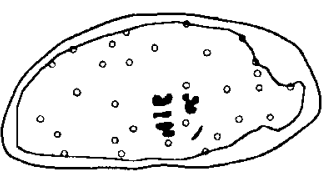

5

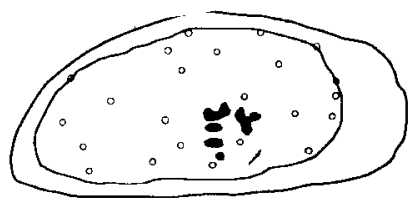

6

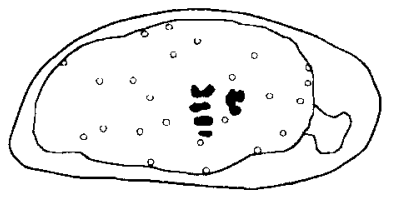

8

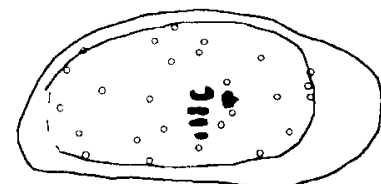

9

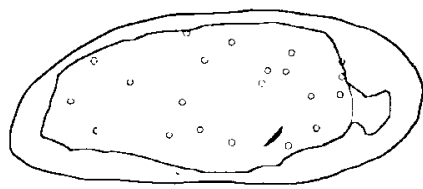

11

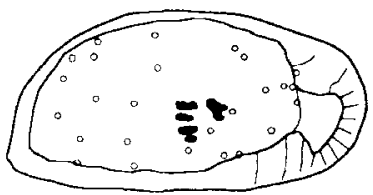

12

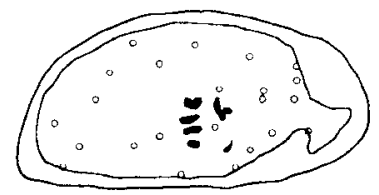

14

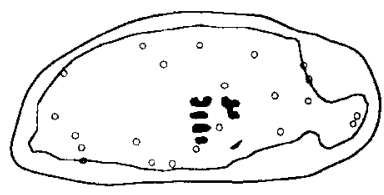

15

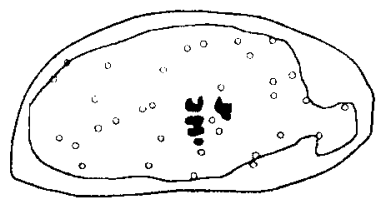

17

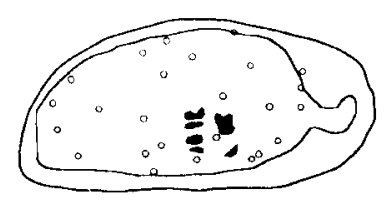

18

scale

$=0.30 \mathrm{~mm}$

Fig. 4. Line drawings of individuals of Krithe cushmani collected from chalk and marl; sample CC collected from marl, other samples collected from relatively pure chalk; all apparently females except 4.1 , all right valves; all at same scale (bottom of figure). figs 4.1, 4.2 collected from sample CC; 4.1 specimen CC80-6; 4.2 specimen CC80-8. figs 4.3, 4.4, 4.5, 4.6, 4.7 collected from sample AS2.5; 4.3 specimen AS2.5-3; 4.4 specimen AS2.5-5; 4.5 specimen AS2.5-6; 4.6 specimen AS2.5-8; 4.7 specimen AS2.5-9. figs. 4.8, 4.9 collected from sample AS4.5; 4.8 specimen AS4.5-5, 4.9 specimen AS4.56. figs. 4.10, 4.11 collected from sample AS7.5; 4.10 specimen AS7.5-3; 4.11 specimen AS7.5-8. figs. 4.12, 4.13 collected from sample AS13.5; 4.12 specimen AS13.5-1; 4.13 specimen AS13.5-2. figs. 4.14, 4.15, 4.16, 4.17 collected from sample KH35; 4.14 specimen KH35-1; 4.15 specimen KH35-2; 4.16 specimen KH35-3; 4.17 specimen KH35-4. fig. 4.18 collected from sample KHS115, specimen KH115-9. Note: Individuals drawn without a vestibulum (e.g. figs $4.6,4.9,4.10$ ) displayed a poorly defined or diagenetically altered vestibulum, and details of this character were not shown, as they would be misleading. 
Krithe from the Campanian and Maastrichtian

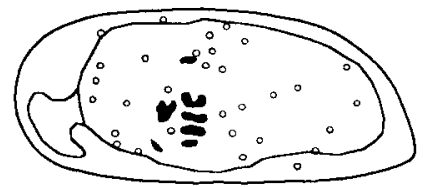

1

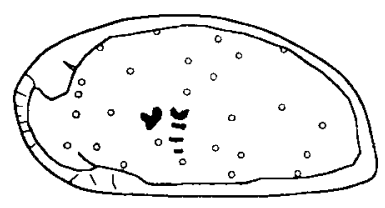

4

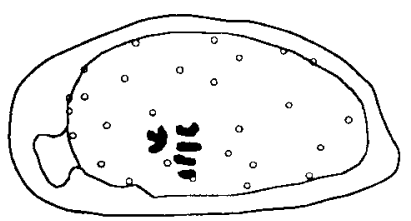

7

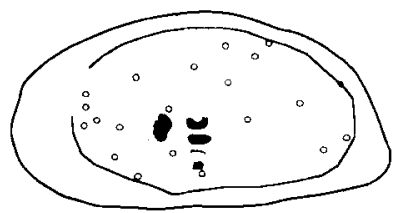

10

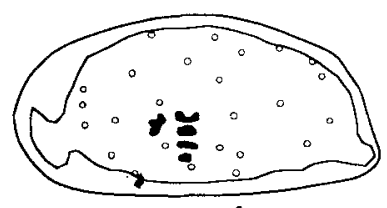

13

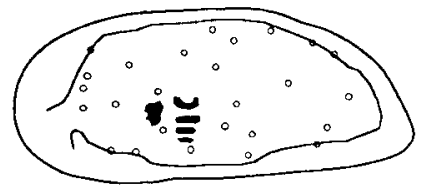

16

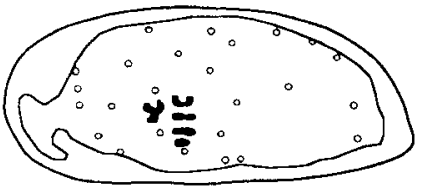

2

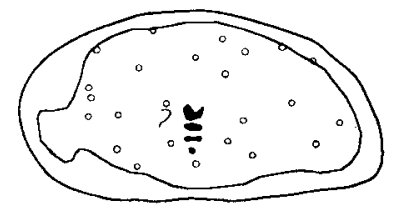

5

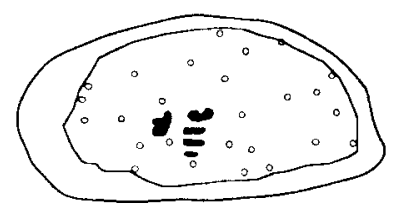

8

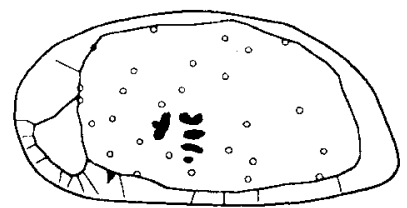

11

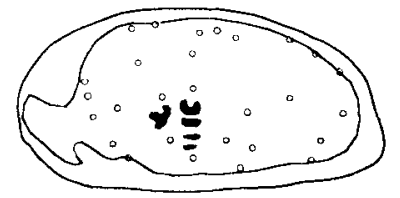

14

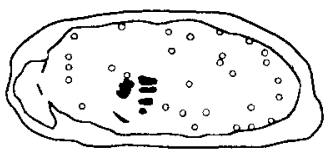

17

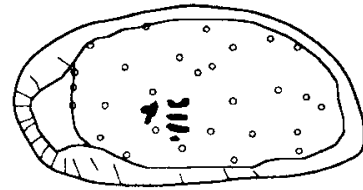

3

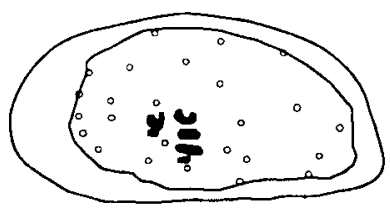

6

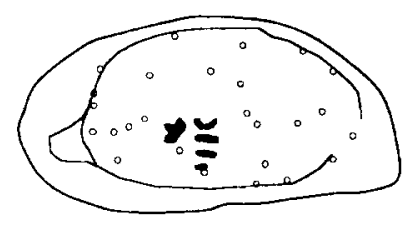

9

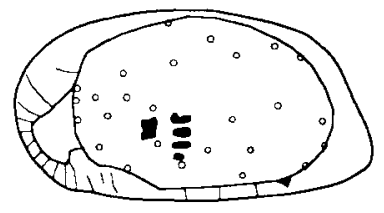

12

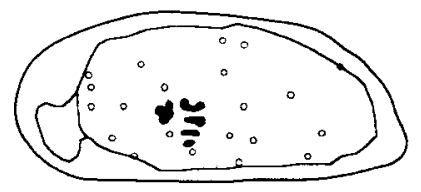

15

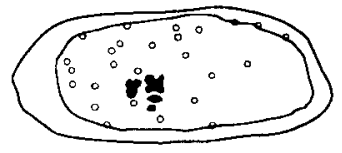

18

scale

$=0.30 \mathrm{~mm}$

Fig. 5. Line drawings of individuals of Krithe cushmani collected from chalk and marl; sample CC collected from marl, other samples collected from relatively pure chalk; all apparently females except 3.17 and 3.18, which are males, all LVs; all at same scale (bottom of figure). figs 5.1, 5.2, 5.3, 5.4 collected from sample CC80; 5.1 specimen CC80-1, 5.2 specimen CC80-11, 5.3 specimen CC80-12, 5.4 specimen CC80-13. figs 5.5, 5.6 collected from sample AS2.5; 5.5 specimen AS2.5-2, 5.6 specimen AS2.5-7. figs 5.7, 5.8 collected from sample AS4.5; 5.7 specimen AS4.5-2, 5.8 specimen AS4.5-3. figs 5.9, 5.10 collected from sample AS7.5; 5.9 specimen AS7.5-1, 5.10 specimen AS7.5-5. fig. 5.11 collected from sample AS10.5, specimen AS10.5-1. fig. 5.12 collected from sample AS13.5, specimen AS13.5-7. figs 5.13, 5.14, 5.15, 5.16 collected from sample KHS115; 5.13 specimen KHS115-6, 5.14 specimen KHS1 15-7, 5.15 specimen KHS1 15-8, 5.16 specimen KHS1 1 S-11. fig. 5.17 collected from sample CC80, specimen CC80-5. fig. 5.18 collected from sample AS2.5, specimen AS2.5-4. Note: Individuals drawn without a vestibulum (e.g. figs 5.6, 5.8, 5.10, 5.16, 5.18) displayed a poorly defined or diagenetically altered vestibulum, and details of this character were not shown, as they would be misleading. 

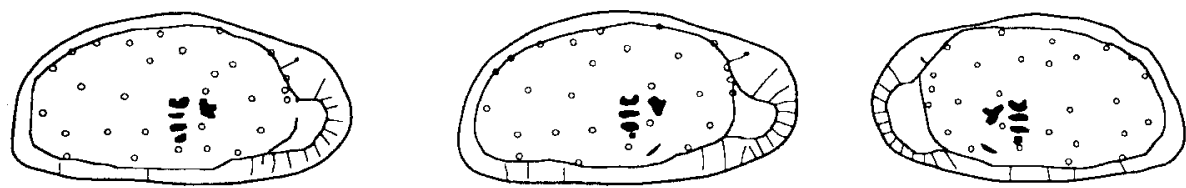

1

2
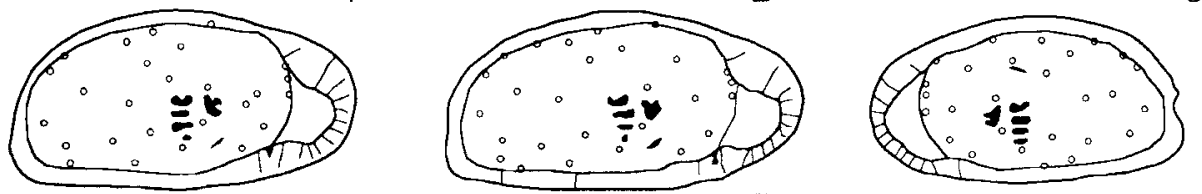

4

5
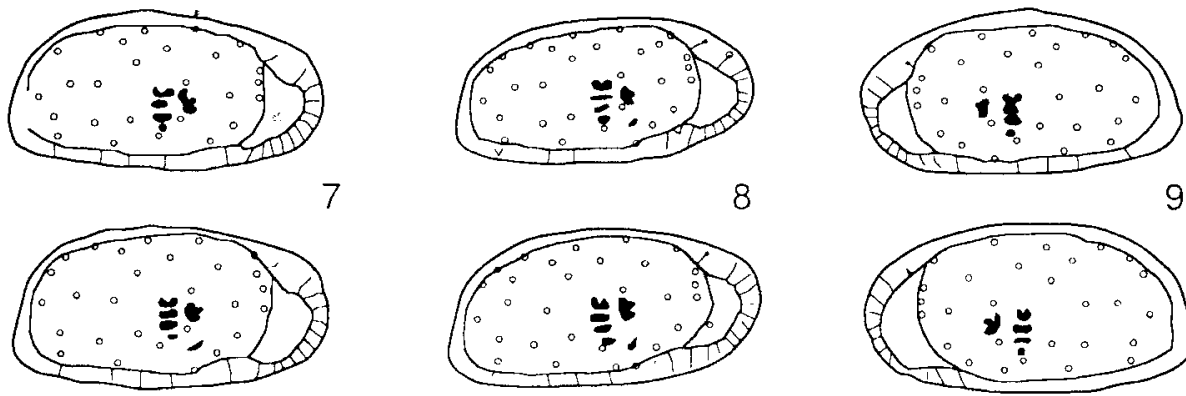

8

9

10
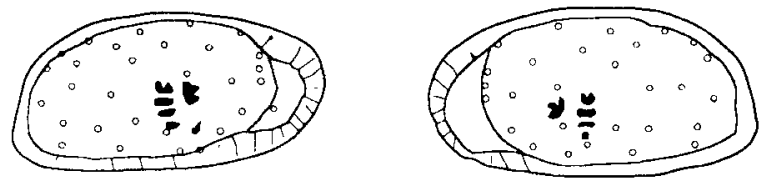

11
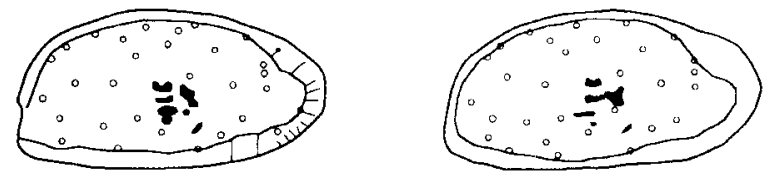

12

13

14
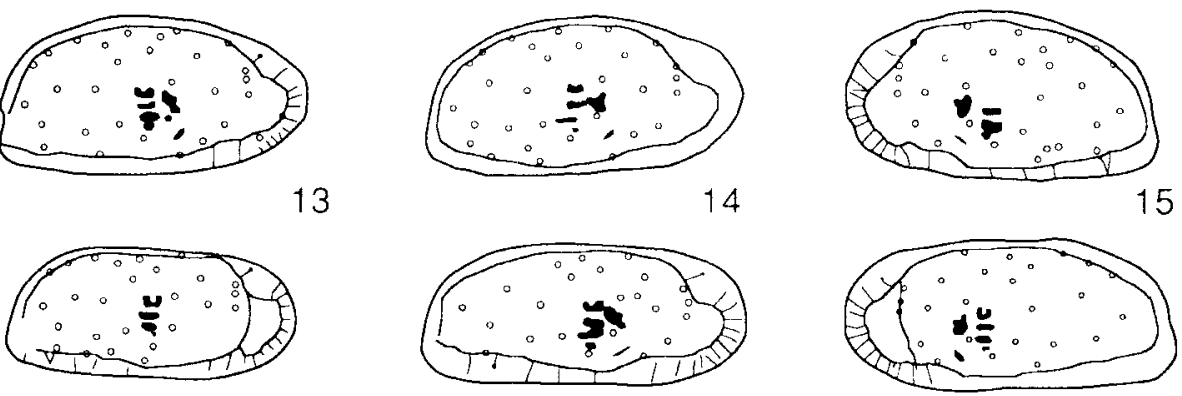

16

17
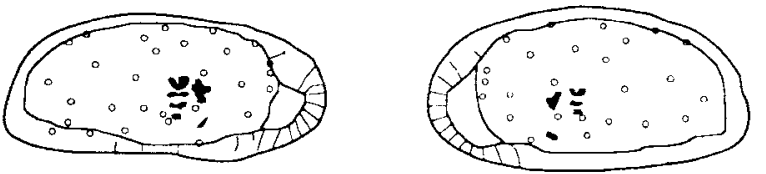

20

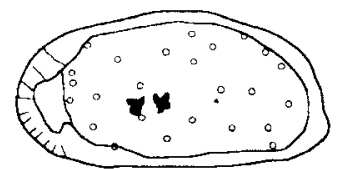

19

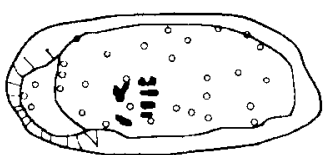

23

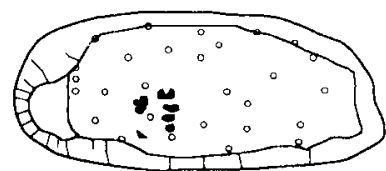

22

24

scale

$=0.30 \mathrm{~mm}$

Fig. 6. Line drawing of individuals of Krithe cushmani collected from nearshore deposits; all at same scale (bottom of figure). figs 6.1, 6.2, 6.4, 6.5 collected from sample 90-11-16-1b; 6.1 female RV, specimen 90-11-16-1b-2, 6.2 female RV, specimen 90-11-16-1b-3, 6.4 female RV, specimen 90-1116-1b-4, 6.5 90-11-16-1b-5, figs 6.3, 6.6, 6.7, 6.8, 6.9, 6.10, 6.11, 6.12, 6.13, 6.16, 6.20, 6.21, 6.23, 6.24 collected from sample 92-5-7-1, 6.3 female RV, specimen 92-5-7-1-4, 6.6 female LV, specimen 92-5-7-1-5, 6.7 female RV, specimen 92-5-7-1-8, 6.8 female RV, specimen 92-5-7-1-9, 6.9 female LV, specimen 92-5-7-1-6, 6.10 female RV, specimen 92-5-7-1-10, 6.11 female RV, specimen 92-5-7-1- 11, 6.12 female LV, specimen 92-5-7-1-14, 6.13 female RV, specimen 92-5-7-1-12, 6.16 male RV, specimen 92-5-7-1-17, 6.20 female RV, specimen 92-5-7-1-2, 21 female RV, specimen 92-5-7-1-17, 6.23 male RV, specimen 92-5-7-1-15, 6.24 male RV, specimen 92-5-7-1-16. figs 6.14, 6.15, 6.17, 6.18, 6.19 collected from sample 91-8-14-1, apparently all females; 6.14 specimen 91-8-14-1-1, 6.15 specimen 91-8-14-1-5, 6.17 specimen 91-8-14-1-2, 6.18 specimen 91-8-14-1-3, 6.19 specimen 91-8-14-1-6. 6.22 collected from sample 90-11-16-1b, male (?) LV, specimen 90-11-16-1b-1. 


\author{
SYSTEMATIC DESCRIPTIONS \\ Suborder Podocopina Sars, 1866 \\ Superfamily Cytheracea Baird, 1850 \\ Family Krithidae Mandelstam in Bubikyan, 1958 \\ Genus Krithe Brady et al., 1874 \\ Krithe cushmani Alexander, 1929 \\ (Pl. 1, figs 1-10, figs 3-6)
}

1929 Krithe cushmani Alexander: 67-68, pl. 4, figs 9, 11.

1939 Krithe cushmani Alexander; Alexander: 66.

1940 Krithe cushmani Alexander; Bonnema: 118, pl. 2, figs 48-

54.

1946 Krithe cushmani Alexander; van den Bold: 77, pl. 4, fig. 18. 1948 Krithe postprojecta Schmidt: 409-410, pl. 61, fig. 8, text-fig. $2 \mathrm{~d}$.

1952 Krithe cf. $K$. postprojecta Schmidt; Swain: 87, pl. 9, fig. 11. 1957 Krithe cushmani Alexander; Butler \& Jones: 17, pl. 1, fig. 2. 1958 Krithe cushmani Alexander; Howe \& Laurencich: 377, textfig. p. 377 (top).

1958 Krithe postprojecta Schmidt; Howe \& Laurencich: 377, text-fig. p. 377 (bottom).

1964 Krithe swaini Benson \& Tatro: 17, pl. 6, figs 16, 18, 19, 20. 1965 Krithe whitecliffsensis Crane: 204, pl. 2, figs 9a, b, c. 1966 Krithe cushmani Alexander; Herrig: 799-800, pl. 14, figs 3 5.

1978 Krithe whitecliffsensis Crane; Smith: pl. 2, figs. 22, 25, 26. 1994 Krithe whitecliffensis [sic] Crane; Pitakpaivan \& Hazel: fig. 5.5 .

Because of the morphologic variability displayed by individuals of each species of Krithe, different methodologies have been proposed to encode this information in the species' names. Peypouquet (1979) departed from traditional, binominal nomenclature by proposing a system using the following code example: Krithe sp. X (often a letter symbolizing groups of individuals considered to represent a single species).number symbolizing relative size $(1=$ small, $2=$ medium, and $3=$ large).number symbolizing relative size of vestibule $(0=$ absent, $1=$ small, $2=$ medium and $3=$ large).letter symbolizing relative thickness of shell $((\mathrm{f}=$ fines (thin) or $\mathrm{e}=$ épaisses (thick)).letter symbolizing hinge type $(\mathrm{n}=$ normal, $\mathrm{i}=$ inverse). Thus, an individual identified as Krithe sp. X.1.2.f.n means that it belongs to species "X," is relatively small, has a moderately large vestibule, is relatively thin shelled, and has a normal hinge. In the case of the individuals of Krithe collected from the Upper Cretaceous of the Gulf Coastal Plain, those collected from the chalk should be referred to as Krithe cushmani.3.1.n (no differentiation of shell thickness is made), and those collected from the nearshore deposits should be referred to as Krithe cushmani.1.3.n.

Using the scheme of Peypouquet (1979) tends to result, therefore, in a relatively low number of species that display a wide range of variability.

Alternatively, Coles et al. (1994) adopted a more traditional approach to the taxonomy of Krithe by considering some morphological features or combination of features to be diagnostic, that is, to be due to intraspecifically variablity or useful only at some level of taxonomy higher than the species level. Such characters as size, shape, degree of sexual dimorphism, and (particulariy) the number, arrangement, and length of anterior, marginal pore canals, are important in recognizing and discriminating species. The result of this latter approach to the taxonomy of species of Krithe is a larger number of species with relatively less intraspecific variability. With regard to the species' identification of the Upper Cretaceous Krithe from the US Gulf Coast, the number and arrangement of radial pore canals are considered to be of primary importance.

The terminology defined by Coles et al. (1994) generally will be followed herein to describe the morphology of Krithe cushmani, with some simplification. The anterior radial pore canals (RPC) as described herein include all those emerging from the anterodorsal portion of the line of concrescence, the vestibule, and the posterodorsal line of concrescence. Coles et al. (1994) differentiated those RPCs emerging from the anterior part of the line of concrescence as opposed to those emerging from the vestibule, ostensibly because the RPCs emerging from the anterodorsal line of concrescence are actually false marginal pore canals that terminate within the inner lamella and were more useful in species recognition than those emerging from elsewhere. As with Coles et al. (1994), the following initials are used: LV (left valve), RV (right valve), FLV (female left valve), FRV (female right valve), MLV (male left valve), MRV (male right valve), NPC (normal pore canals), FRPC (false radial pore canals), ARPC (anterior radial pore canals), VRPC (ventral radial pore canals), and PRPC (posterior radial pore canals). USNM refers to the US National Museum.

Description. Sexually dimorphic; females with arched dorsum, males with nearly straight dorsum and lower height:length ratio, being more elongate. Surface smooth. Adults with incised pit at posterior end of both valves. As many as 30 NPC on each valve, all in relatively constant position; greater number and size of NPC on individuals from nearshore deposits. Inner lamella moderately wide. Anterior vestibulum either mushroom shaped (found in those collected from chalk) or pocket shaped (open posteriorly) (found in those collected from calcareous clay or marl). Thirteen ARPC, including anterodorsal FRPC and two false radial pore canals emergent from posterior portion of vestibule. Hinge adont. Muscle scars include vertical column of four adductor muscle scars, increasing in size dorsally, with dorsal scar U-shaped, middle two elongate and slightly constricted medially, and ventral adductor scar subcircular; frontal scar trilobate or, rarely, unfused and forming small circular scar bordered anteriorly and dorsally by bilobed scar; mandibular scar thin crescent (concave directed posterodorsally), located posteriorly of frontal scar.

Remarks. As mentioned previously, much of the confusion regarding the alpha taxonomy of Krithe from the Upper Cretaceous of North America was because the pits at the posterior margin of the carapace were not originally described. All of the adult individuals of Krithe observed during the present study have this pit, although some juveniles lack pits. The presence of pits occurring at the posterior end of the carapace is a character found in most of not all adult species of the genus, and it is likely that they are present on the holotype of $K$. cushmani. The Alexander collection of microfossils, in which the holotype of Krithe cushmani is reposited, is currently unavailable for study, and has been so for well over a decade. 


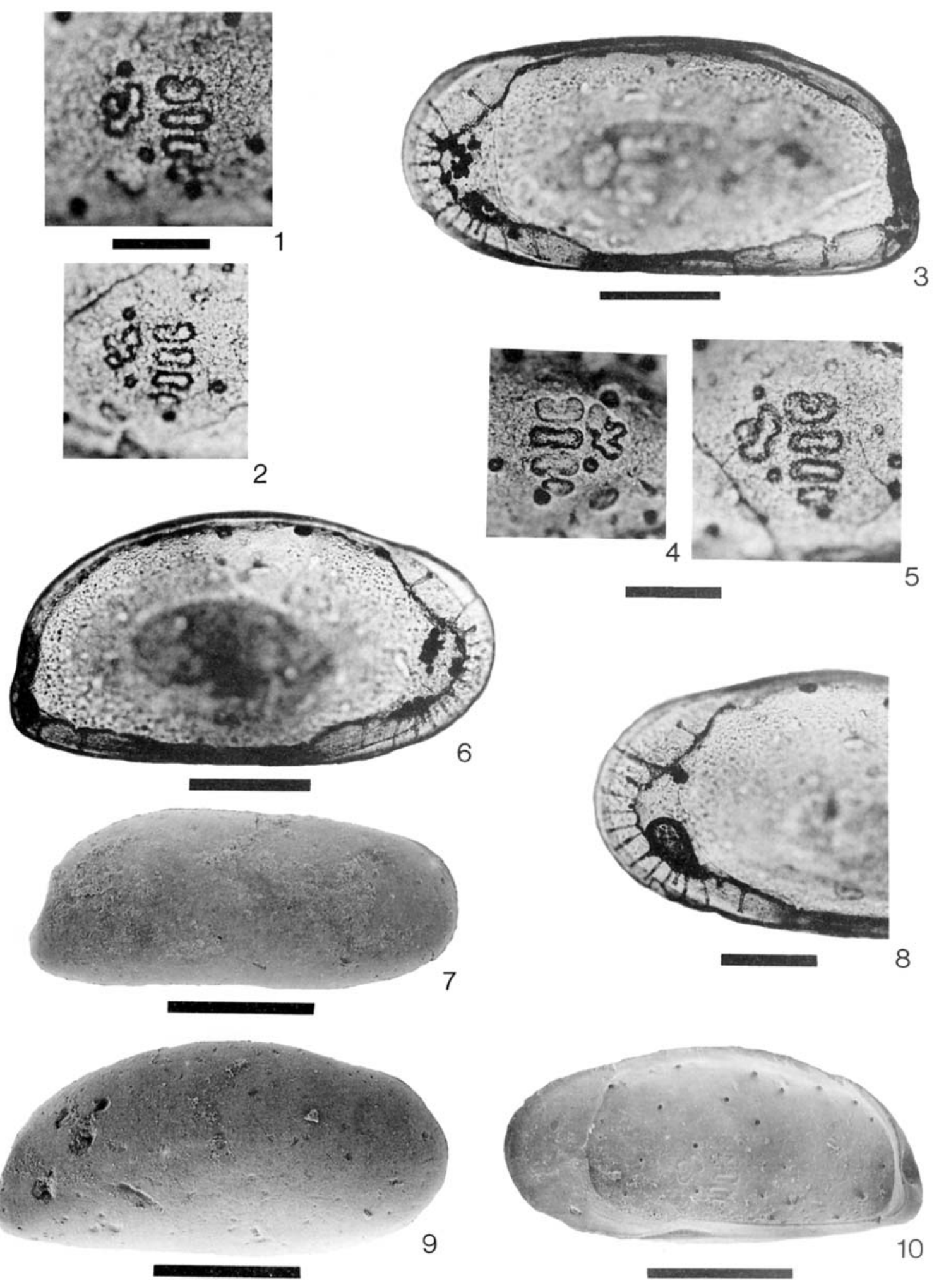


The type specimens of Krithe postprojecta [USNM holotype (an LV) 104190a, and a paratype (an LV, broken at the anteroventral end) 104190b] were examined. The projecting posteroventral margin is not as noticeable in the paratype as in the holotype. The widest part of the holotype is in the middle, and the valve becomes more compressed anteriorly and is nearly flat at its anterior end. The individuals interpreted herein to be males of Krithe cushmani collected for this study correspond fairly well to the type specimens of Krithe postprojecta but are slightly more rounded in the anterior region. These individuals are characterized by subparallel dorsal and ventral margins, in contrast to $K$. cushmani, which has a strongly arched dorsum. These morphologic differences are herein considered to be due to sexual dimorphism. The reasoning for this interpretation is largely circumstantial. First, the characteristics of the inner lamella, the configuration of the marginal pore canals, and the shape of the muscle scars between forms characterized as $K$. postprojecta and $K$. cushmani are within the same range of variability. Second, according to van Morkhoven (1963), males of Krithe are less tall and narrower than the females, a relationship seen clearly in the two morphs considered herein. Furthermore, the stratigraphic range or paleoenvironmental occurrence of the two forms apparently is the same. Last, the population structure of the two forms suggests that they are males and females. A total of 745 specimens of $K$. cushmani were picked compared to 114 specimens of $K$. postprojecta, resulting in a ratio of $6.54: 1$. van Harten (1983) stated that most species of ostracodes have a male to female ratio of less than one, and, especially in the nonmarine realm, the ratio can even be zero (parthenogenic populations). Although little quantitative data have been generated on the male: female ratios of species during this study and even less has been published on the male: female ratios for populations of Krithe even though considerable work has been done on their morphology, the typical ratio for marine ostracodes appears to be about one male for every five or ten females. The ratio of $K$. cushmani to $K$. postprojecta falls within this range, suggesting that the ratio between these two morphotypes falls within a common range of male to female ratios. Herrig (1966) figured several specimens of $K$. cushmani, two of which he called males (PI. 14, figs 5a, 5b), which are identical to the forms referred to in previous literature as $K$. postprojecta. For all of these reasons, $K$. postprojecta is herein considered to be a male of $K$. cushmani.

The positions of the NPC are very similar on all specimens collected from the Upper Cretaceous deposits of the northern Gulf Coastal Plain, although they are fewer in number on specimens collected from the chalk (cf. Figs 4-6). The number and arrangement of the ARPC and the VRPC are constant for all individuals of Krithe observed during this study. Figure 3 shows the number and positions of these RCP, although the shape of the vestibulum in specimens collected from the chalk and from the nearshore deposits is different (compare Fig. 3 with Figs 4.12, 4.13, 5.3 and 5.12). Primarily for these reasons, all specimens from the Upper Cretaceous of Alabama and Mississippi are considered to be of the same species.

\section{ECOLOGY}

Analysis of the relationship between morphology of Krithe and palaeoenvironment is based on: (1) morphometric analysis of carapace size, as measured by length and height, area of vestibule, and ratios of these variables and (2) lithologic and paleontologic analyses of the sediments in which each of the samples was collected. Individuals selected for inclusion in this study were collected from either chalk, representing an offshore paleoenvironment; marl, probably deposited in areas intermediate between the chalk and clastic-dominated sediment; or from muddy sands or sandy muds, representing nearshore sedimentation. The samples collected from this intermediate palaeoenvironment (those collected from sample CC) are more similar to the offshore samples than to the nearshore samples. Individuals of Krithe from this sample were also more similar to those collected from the chalk than from the nearshore deposits. The intermediate sample, then is probably not truly intermediate, and has therefore been included with the offshore samples on the table and the outline drawings.

Table 2 presents results of the measurements of vestibule size, carapace length, and ratios of these variables for individuals collected from the offshore deposits, and Table 3 presents these quantities for individuals collected from the nearshore deposits. Figures $7 \mathrm{a}$ and $7 \mathrm{~b}$ present plots of the area of vestibule and carapace length, respectively, for both the nearshore and offshore Krithe faunas, arranged monotonically. Figure $7 \mathrm{c}$ shows the ratio of area of carapace divided by carapace length, also for all specimens used in this study and arranged monotonically. Figure 8 is a plot of the means of the area of vestibule and of the length with bars representing the standard error.

Clearly, the individuals of Krithe collected from the offshore and from the nearshore deposits are morphologically different. The anterior vestibule of individuals collected from the offshore (chalk) areas are mushroom-shaped, while those collected from the nearshore (clastic dominated) areas are of the open type, following the terminology of Coles et al. (1994). Plots of the absolute areas of the vestibules (Fig. 7a) shows that, when the measurements are arranged monotonically, the vestibule areas for the individuals collected in nearshore sediments are larger

\section{Explanation of Plate 1}

Figs 1, 2, 4, 5. Krithe cushmani Alexander, 1929, transmitted light micrographs of closeup of muscle scars; 1, female, LV, specimen CC80-12, barscale below figure equals approximately $0.10 \mathrm{~mm}$, note detachment of anterior portion of frontal muscle scar; 2, female, LV, specimen CB20-1, same scale as Fig. 1, note fusion of antero-medial portion of frontal scar, but detachment of anteroventral portion; 4, male, RV, specimen 91-8-14-1-2, barscale below equals approximately $0.10 \mathrm{~mm}$, note complete fusion of frontal muscle scar elements; 5 , female, LV, specimen CC80-11, same scale as Fig. 4, note detachment of anterior portion of frontal scar. figs 3, 6, 8. Krithe cushmani Alexander, 1929, transmitted light micrographs showing details of marginal radial pore canals and vestibules; 3, female, LV, specimen 91-8-14-1-3, barscale equals approximately $0.20 \mathrm{~mm} ; 6$, female, RV, specimen 91 8-14-1-1, barscale equals approximately $0.20 \mathrm{~mm} ; 8$, female, LV, specimen $91-8-14-1-4$, barscale equals approximately $0.20 \mathrm{~mm}$. figs $7,9,10$. Krithe cushmani Alexander, 1929, scanning electron micrographs contrasting outlines of males and females; 7, male, exterior view, RV, specimen LC 175-1, barscale equals $0.23 \mathrm{~mm} ; 9$, female, exterior view, RV, specimen CC80-15; barscale equals $0.25 \mathrm{~mm}$; 10, female, interior view, RV, showing details of normal pore canals, muscle scars, and pit at posterior end of valve, barscale equals $0.27 \mathrm{~mm}$. 


\begin{tabular}{|c|c|c|c|c|c|c|c|c|}
\hline Specimen number & AS2.5-1 & AS2.5-3 & AS4.5-1 & AS4.5-2 & AS4.5-3 & AS4.5-5 & AS4.5-6 & AS7.5-2 \\
\hline lst measurement & 456 & 380 & 492 & 838 & 645 & 547 & 857 & 644 \\
\hline 2nd measurement & 464 & 383 & 482 & 845 & 643 & 539 & 813 & 653 \\
\hline 3rd measurement & 468 & 382 & 458 & 846 & 646 & 546 & 855 & 645 \\
\hline 4th measurement & 460 & 385 & 511 & 839 & 648 & 549 & 870 & 654 \\
\hline Total & 1848 & 1530 & 1943 & 3368 & 2582 & 2181 & 3395 & 2596 \\
\hline Average & 462 & 383 & 486 & 842 & 646 & 545 & 849 & 649 \\
\hline Length & 621 & 667 & 535 & 584 & 643 & 641 & 646 & 587 \\
\hline Height & 314 & 324 & 279 & 365 & 337 & 324 & 323 & 294 \\
\hline Length/height & 1.98 & 2.06 & 1.92 & 1.60 & 1.91 & 1.98 & 2.00 & 2.00 \\
\hline Area/length & 0.74 & 0.57 & 0.91 & 1.44 & 1.00 & 0.85 & 1.31 & 1.11 \\
\hline Specimen number & AS7.5-3 & AS7.5-5 & AS13.5-1 & AS13.5-2 & AS13.5-8 & KH35-1 & КН35-2 & KH35-3 \\
\hline 1st measurement & 883 & 682 & 769 & 522 & 936 & 601 & 855 & 872 \\
\hline 2nd measurement & 882 & 676 & 768 & 528 & 943 & 597 & 862 & 878 \\
\hline 3rd measurement & 877 & 683 & 764 & 513 & 937 & 607 & 862 & 877 \\
\hline 4th measurement & 884 & 676 & 773 & 514 & 941 & 599 & 865 & 874 \\
\hline Total & 3526 & 2717 & 3074 & 2077 & 3757 & 2404 & 3444 & 3501 \\
\hline Average & 882 & 679 & 769 & 519 & 939 & 601 & 861 & 875 \\
\hline Length & 635 & 658 & 610 & 610 & 623 & 610 & 642 & 625 \\
\hline Height & 336 & 352 & 318 & 326 & 324 & 316 & 306 & 317 \\
\hline Length/height & 1.89 & 1.87 & 1.92 & 1.87 & 1.92 & 1.93 & 2.10 & 1.97 \\
\hline Area/length & 1.39 & 1.03 & 1.26 & 0.85 & 1.51 & 0.99 & 1.34 & 1.40 \\
\hline Specimen number & KH35-4 & KHS115-5 & KHS115-6 & KHS1 15-8 & KHS115-9 & KHS115-10 & KHS115-11 & KHS115-12 \\
\hline lst measurement & 952 & 680 & 591 & 950 & 811 & 904 & 1154 & 1030 \\
\hline 2nd measurement & 955 & 674 & 590 & 956 & 812 & 902 & 1164 & 1042 \\
\hline 3rd measurement & 951 & 683 & 607 & 952 & 810 & 912 & 1169 & 1036 \\
\hline 4th measurement & 945 & 678 & 605 & 953 & 808 & 904 & 1156 & 1043 \\
\hline Total & 3803 & 2715 & 2393 & 3811 & 3241 & 3622 & 4643 & 4151 \\
\hline Average & 951 & 679 & 598 & 953 & 810 & 906 & 1161 & 1038 \\
\hline Length & 638 & 680 & 648 & 680 & 638 & 658 & & 623 \\
\hline Height & 326 & 312 & 337 & 309 & 317 & 332 & 322 & 337 \\
\hline Length/height & 1.96 & 2.18 & 1.92 & 2.20 & 2.01 & 1.98 & & 1.85 \\
\hline Area/length & 1.49 & 1.00 & 0.92 & 1.40 & 1.27 & 1.38 & & 1.67 \\
\hline
\end{tabular}

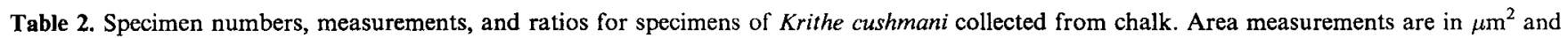
length/height measurements are in $\mu \mathrm{m}$.

than those collected from offshore sediments. Similarly plots of the carapace lengths clearly show the individuals collected from offshore sediments to be longer, with convergence at the extremes of the length. Figure $7 \mathrm{c}$ shows the relative size of the vestibules, taken as a function of the carapace length. Again, the separation of the two populations is clear. There is, however, significant overlap in the absolute values of both the area of the vestibule and the length of the carapace between the two populations. For example, the longest individual collected from nearshore sediments is longer than the shortest individual collected from the chalk. Last, the number and size of the normal pore canals are greater on the individuals collected from the nearshore deposits.

Some evidence suggests that the benthic habitats in areas undergoing chalk deposition had lower oxygen concentrations, certainly not anaerobic and probably not dysaerobic, but kenoxic (a term adopted by Cepek \& Kemper, (1981) and applied by Whatley (1990) to imply 'moderate concentrations of oxygen,' rather than anaerobia). Whatley (1991) suggested that ostracode faunas dominated by Cytherella indicate kenoxic conditions, the reasons for which were given in a previous section. Puckett (1992) showed that Cytherella is overwhelmingly dominant in the chalk of Alabama and Mississippi and in fact is so in some of the same samples used in this study, and the diversity of the ostracode faunas in the chalk is markedly lower than coeval nearshore deposits. The presence of pyrite, as pyritized coprolites or burrows and at the sites of muscle attachment on large bivalves, suggests at least local reducing microenvironments such as those around decaying organic matter. These observations suggest kenoxic conditions.

The Demopolis Chalk is, however, thoroughly bioturbated (Frey \& Bromley, 1985), including several ichnogenera of various sizes. The absence of an abundant macrobenthos in the chalk is probably related more to the thixotropic nature of the substrate rather than any chemical feature of the seawater (Frey \& Bromley, 1985). What is not clear is whether the 


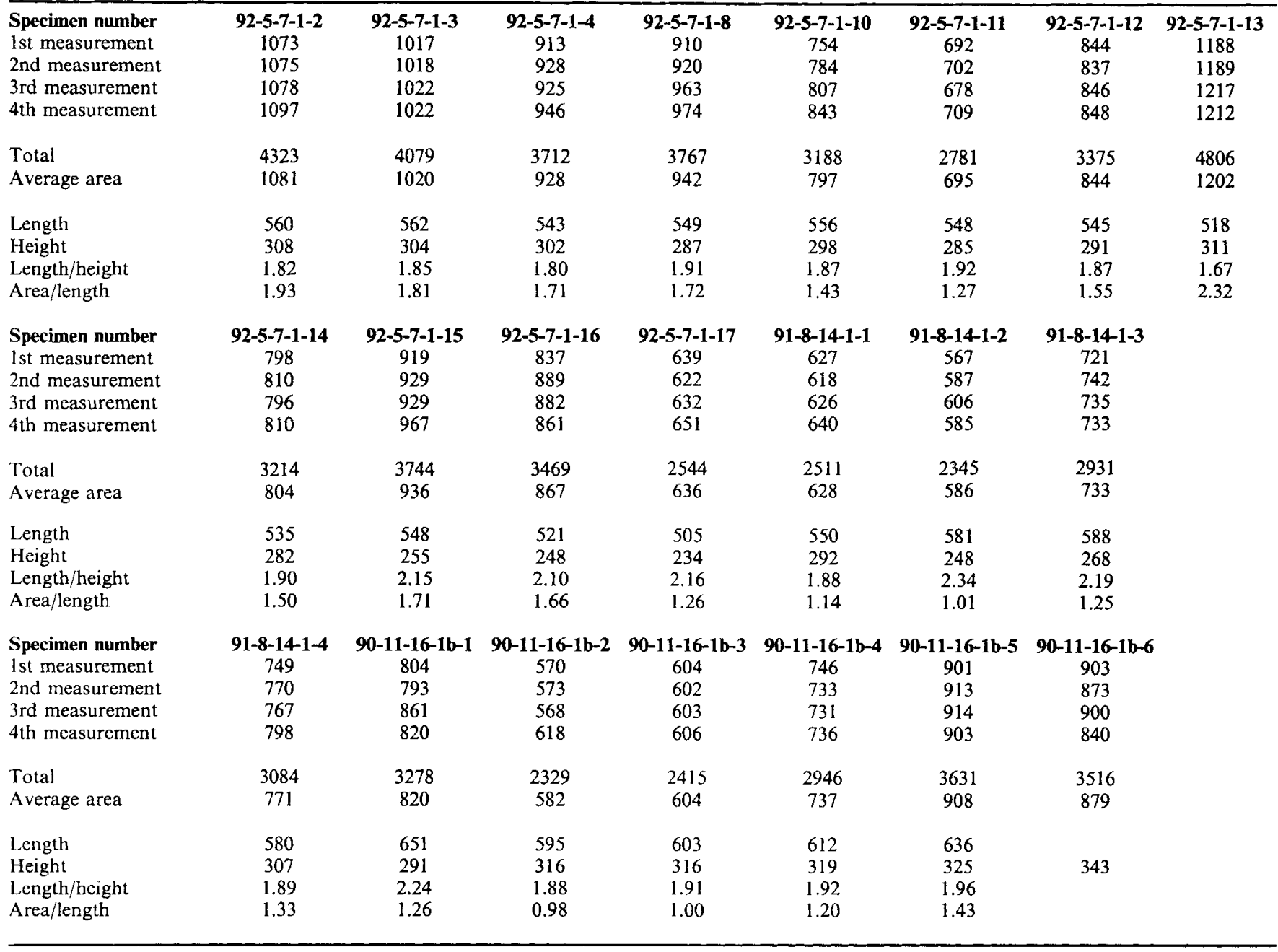

Table 3. Specimen numbers, measurements, and ratios for specimens of Krithe cushmani collected from nearshore deposits. Area measurements are in $\mu \mathrm{m}^{2}$ and length/height measurements are in $\mu \mathrm{m}$.

dominance of Cytherella is because they were able to tolerate a moderately reduced oxygen concentration or were able to take advantage of the type of food resources available in the chalk. This latter factor undoubtedly inhibited many ostracode species living in the more nearshore, terrigenous-clastic-dominated areas in eastern Alabama and northern Mississippi. The chronology of trace fossils in the Demopolis Chalk suggests that the sediment immediately below the original sea floor had a high organic content (Frey \& Bromley, 1985) and thus a large amount of potential food was available for the benthos. The extremely fine-grained nature of this food resource (i.e. nannofossil ooze) and the soupy texture of the substrate may have inhibited some species of ostracodes from taking advantage of this food resource, such as those species that eat organic matter coating sand grains. The thixotropic nature of the chalky substrate was also probably a factor in reducing diversity by precluding inhabitation by taxa that live interstitially, such as the smaller ostracode genera Loxoconcha and Eucytherura. The extremely fine-grained nature of the sediment in the chalk sea is also possibly responsible for the smaller number and size of normal pore canals on individuals of Krithe cushmani collected from these deposits. Puckett (1996) interpreted the difference between two very closely related taxa of ostracodes, Haplocytheridea renfroensis renfroensis Crane, 1965 , and $H$. renfroensis dilatipuncta Crane, 1965, differing only in the size of normal pore canals, to be due to the difference in the substrate in which they lived. Haplocytheridea renfroensis renfroensis, bearing large, open, normal pore canals, is far more common in terrigenousclastic-dominated sediment, whereas $H$. renfroensis dilatipuncta, characterized by vestigial normal pore canals usually observable only by transmitted light, occurs only in the chalk.

The relative contribution of oxygen concentration and food resources that resulted in the low-diversity, Cytherella-dominated ostracode assemblages occurring in the chalk and in which the offshore Krithe individuals were collected for this study, is not precisely known. Probably both factors contributed to make the chalk a relatively inhospitable place for ostracodes to live. Indications are that the food supply was abundant, but of a specific type that limited the distribution of some species of ostracodes (i.e. nannoplankton and fecal material raining down 

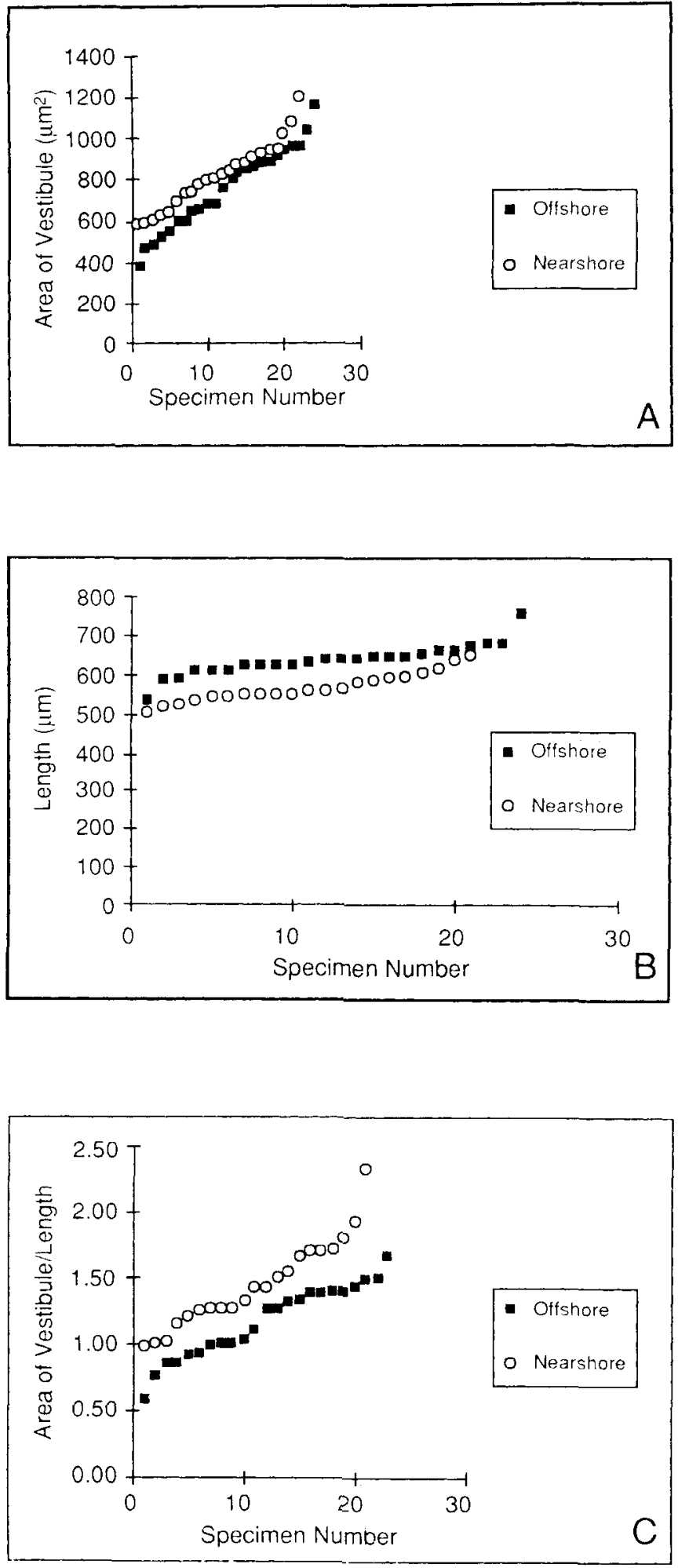

Fig. 7. Bivariate plots of measurements of individuals of Krithe cushmani. (a) Averages of the area of vestibule (in $\mu \mathrm{m}^{2}$ ) of the individuals arranged monotonically. (b) Length (in $\mu \mathrm{m}$ ) of the individuals arranged monotonically. (c) Ratio of area of vestibule divided by the length of the individuals arranged monotonically.

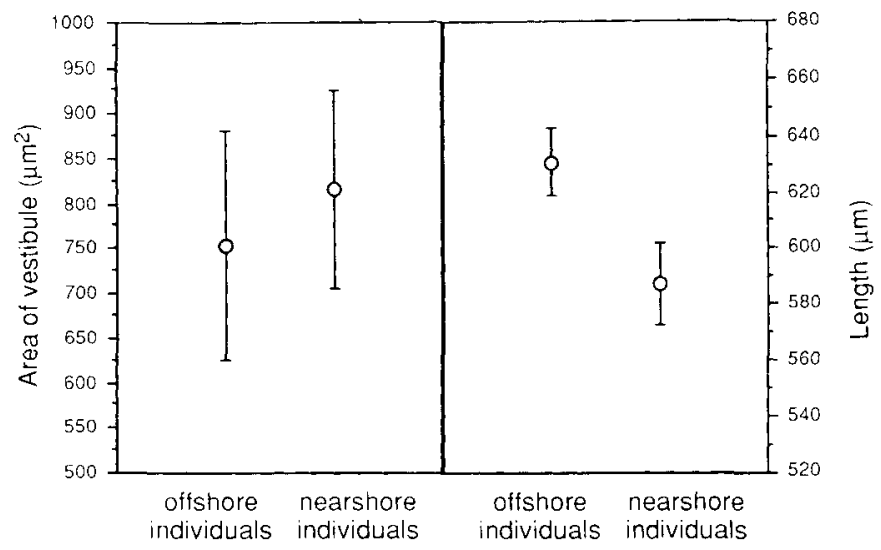

Fig. 8. Means (circles) and standard error bars (lines) of the areas of the vestibules and the lengths.

from the water column), and oxygen concentration was probably somewhat reduced from normal, especially below the sediment-water interface.

\section{SUMMARY AND CONCLUSIONS}

All individuals of Krithe found in the Upper Cretaceous deposits of Mississippi and Alabama, northern US Gulf Coastal Plain, are considered to belong to one species, Krithe cushmani Alexander, 1929. The lack of recognition of sexual dimorphism and the presence of pits at the posterior margin of the adult carapaces account for the troubled taxonomic history of this species. The females are larger and more arched dorsally than the males, and the posteroventral margin of the males is slightly protuberant. At least two morphotypes, other than the sexual dimorphs, are present, however, and are distinguished mainly by observation through transmitted light. Individuals collected from the nearshore, clastic-dominated deposits are slightly smaller, have an open-type vestibule that is relatively larger, and have larger and more numerous normal pore canals. Individuals from the chalk and marl are slightly larger, have a mushroom-shaped vestibule that is relatively small, and smaller and less numerous normal pore canals.

Based on the hypotheses of Peypouquet (1975, 1977, 1979), the anterior vestibule of individuals of Krithe from the chalk was initially hypothesized to be larger than in those from coeval nearshore deposits, as there is some suggestion that the benthic habitat was of slightly reduced oxygen concentration. In fact, the anterior vestibules are relatively smaller. The absolute size of individuals of Krithe living in the chalk was, however, somewhat larger than those living in the nearshore areas. Clearly, some factor or combination of factors in the palaeoenvironments during the Late Cretaceous exerted control over the morphology of these individuals, because each of the two morphotypes analysed in this study is restricted to a specific palaeoenvironment. The combination of slight differences in oxygen concentrations, particularly in microenvironments within the chalky substrate, and the nature of the sediment in the chalk sea may have been important environmental parameters influencing the 
morphology of individuals of Krithe cushmani during the Late Cretaceous.

\section{ACKNOWLEDGEMENTS}

Sincerest thanks are extended to Dr Roger L. Kaesler, Palaeontological Institute, University of Kansas, USA, for reviewing an early draft of this paper and for stimulating discussions, both of which resulted in significant improvements in the manuscript. Dr Graham P. Coles, The Geochem Group of Companies, Chester, UK, and Drs Jean-Pierre Peypouquet and Thierry Corrège, Université Bordeaux, France, are sincerely thanked for their careful reviews of the manuscript and interesting discussions regarding the taxonomy and morphology of Krithe.

\section{Manuscript received November 1994 \\ Manuscript accepted May 1995}

\section{REFERENCES}

Abacus Concepts, 1992. Statview, version 4.0, Abacus Concepts, Inc., Berkeley.

Alexander, C. I. 1929. The Ostracoda of the Cretaceous of north Texas. Bulletin of the University of Texas, 2907: 1-137.

Benson, R. H., \& Tatro, J. O. 1964. Faunal description of Ostracoda of the Marlbrook Marl (Campanian), Arkansas. The University of Kansas Paleontological Contributions, Article 7: 1-32.

Cepek, P. \& Kemper, E. 1981. Der Blattertonstein des nordwestdeutschen Barreme und die Bedeutung des Nannoplanktons für die fein laminierten, anoxisch entstandenen Gestein. Geologische Jahrbuch Hannover, A58: 3-13.

Coles, G. P., Whatley, R. C. \& Moguilevsky, A. 1994. The ostracod genus Krithe from the Tertiary and Quaternary of the North Atlantic. Palaeontology, 37: 71-120.

Crane, M. J. 1965. Upper Cretaceous ostracodes of the Gulf Coast. Micropaleontology, 11: 191-254.

Davis, J. C. 1986. Statistics and Data Analysis in Geology, 646 pp. Wiley, New York.

Frey, R. W. \& Bromley, R. G. 1985. Ichnology of American chalks: the Selma Group (Upper Cretaceous), western Alabama. Canadian Journal of Earth Science, 22: 801-828.

Herrig, E. 1966. Die Ostracoden aus der Weißen Schreibkreide (UnterMaastricht) der Insel Rügen. Paläontologische Abhandlungen A, II(4): 693-1024.

Kellaway, F. W. 1968. The Penguin-Honeywell Book of Tables, 75 pp. Penguin Books, Harmondsworth.
McKenzie, K. G., Majoran, S., Emami, V. \& Reyment, R. A. 1989. The Krithe problem - first test of Peypouquet's hypothesis, with a redescription of Krithe praetexta praetexta (Crustacea, Ostracoda). Palaeogeography, Palaeoclimatology, Palaeoecology, 74: 343-354.

Peypouquet, J.-P. 1975. Les variations des caracteres morphologiques internes chex les ostracodes des genres Krithe et Parakrithe: rélation possible avec la teneut en $\mathrm{O}_{2}$ dissous dans l'eau. Bulletin de l'Institut Géologique de bassin d'Aquitaine, 17: 81-88.

Peypouquet, J.-P. 1977. Les ostracodes et la connaissance des paléomilieux profonds. Applications au Cénozoïque de l'Atlantique nord-oriental. Thèse de Doctorat d'État és Sciences, Université de Bordeaux, 450.

Peypouquet, J.-P. 1979. Ostracodes et paléoenvironnements. Methods et application aux domaines profonds du Cénozoïque. Bulletin du Bureau de Recherches Géologiques et Minières (deuxieme serie), Section IV, Bordeaux, 1: 3-79.

Peypouquet, J.-P., Grousset, F. \& Mourguiart, P. 1986. Paleooceanography of the Mesogean Sea based on ostracods of the northern Tunisian continental shelf between the Late Cretaceous and early Paleogene. Geologische Rundschau, 75: 154-174.

Puckett, T. M. 1992. Distribution of ostracodes in the Upper Cretaceous (late Santonian through middle Maastrichtian) of Alabama and Mississippi. Transactions of the Gulf Coast Association of Geological Societies, 42: 613-631.

Puckett, T. M. 1996. Ecologic atlas of Upper Cretaceous ostracodes of Alabama. Alabama Geological Survey Monograph 14, 176 pp..

Rasband, W. 1992. Image, 1.44, National Institutes of Health, Research Services Branch, NIMH, Washington, DC.

Schmidt, R. A. M. 1948. Ostracoda from the Upper Cretaceous and lower Eocene of Maryland, Delaware, and Virginia. Journal of Paleontology, 22: 389-431.

Swain, F. M. 1952. Ostracoda from wells in North Carolina. US Geological Survey Professional Paper 234-B, 59-93.

van Harten, D. 1983. Resource competition as a possible cause of sex ratio in benthic ostracodes. In Maddocks, R. F. (Ed.) Applications of Ostracoda, 568-580. Department of Geosciences, University of Houston, Houston.

van Morkhoven, F. P. C. M. 1963. Post-Palaeozoic Ostracoda, vol. II, 478 pp., Elsevier, Amsterdam.

van Morkhoven, F. P. C. M. 1972. Bathymetry of Recent marine Ostracoda in the northwest Gulf of Mexico. Transactions of the Gulf Coast Association of Geological Societies, 22: 241-252.

Whatley, R. C. 1990. Ostracoda and global events. In Whatley, R. C. \& Maybury, C. (Eds) Ostracoda and Global Events, 3-24. Chapman and Hall, London.

Whatley, R. C. 1991. The platycopid signal: a means of detecting kenoxic events using Ostracoda. Journal of Micropalaeontology, 10: 181-185.

Whatley, R. C. \& Quanhong, Z. 1993. The Krithe problem: A case history of the distribution of Krithe and Parakrithe (Crustacea, Ostracoda) in the South China Sea. Palaeogeography, Palaeoclimatology, Palaeoecology, 103: 281-297. 